症例

空腸に内瘦を形成した遺伝性非ポリポーシス大腸癌の 1 例

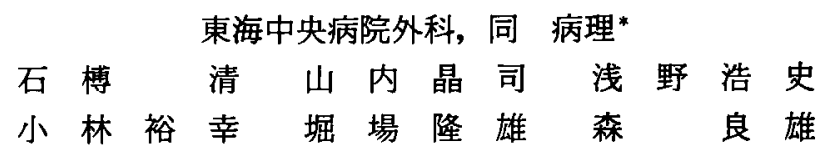

症例は48歳の男性て, 乫然の下痢と体重隇少を主訴に来院した. $\mathrm{S}$ 状結腸癌, 下行結腸 癌の既往歴あり，父，叔父，弟に大腸癌の家族歴があった，注腸造影，大腸内視鏡検查 で空腸瘦を形成した横行結腸癌, 早期直腸癌と診断, さらに術中検索で盲腸にも隆起病 変を認めた。結腸严全摘術に瘦孔部の空腸合併切除を施行, 直腸病変は二期的に経仙骨 式に全層切除した．組織学的には横行結腸の腫瘍は高分化腺癌, si.n1. P0. H0. M (-). stage IIIa, 盲腸, 直腸の病変は早期癌であった。本症は遺伝性非ポリポーシス大腸癌の 1 家系でっった.内瘻形成した大腸癌と遺伝性非ポリポーシス大腸癌はいずれも比較的 若年発症であること, 臨床所見の割に予後が比較的良いこと, 組織学的に粘液癌の頻度 が一般大腸癌と比べ高いことなど,共通する特徽を有しており興味ある症例と思われた。

索引用語：遺伝性非ポリポーシス大腸癌, 空腸結腸瘦, 消化管内㿉

\section{緒 言}

遗伝性非ポリポーシス大腸癌 (Herediatary Nonpolyposis Colorectal Cancer 以下, HNPCC と略 記)は, 同一家系内に大腸癌患者が集積し, 若年発症, 右半結腸好発, 多発癌, 多臟器重複癌の高率合併を特 徵とする. 進行大腸癌では陊接葴器に直接浸潤するこ とは比較的多いが，他の消化管との間に内㿉を形成す ることは稀である，今回われわれは，空腸に内㿉を形 成した HNPCCの 1 例を経験したので文献的考察を 加えて報告する。

症 例

患者：48藏, 男性.

主訴:下痢と体重減少.

家族歴：特記すべきものなし.

既往歴：1990年 S 状結腸癌のため S 状結腸切除術 (well. ss. ly3.v1. n0)，1992年下行結腸ポリープのた め内視鏡的切除 (cancer with adenoma. well. sm2. ly1.v0)をうけていた.

現病歴：1995年 4 月某日, 1 日 7,8 行の水様性下 痢が乫然出現し，市販の止痢剂を服用したが軽快しな かった. 5 月になってたちくらみも出現するようにな り当科受診. 3 力月間に $5 \mathrm{~kg}$ の体重減少を認めた。

1997年 9 月 16 日受付 1997 年12月 3 日採用
現症：身長 $158 \mathrm{~cm}$, 体重 $44 \mathrm{~kg}$, 体格小。眼瞼結膜に 負血を認めたが眼球結膜には黄疸を認めず。表在リン 八゚節は触知しなかった。腹部は平坦で柔らかく腫瘤触 知せず，圧痛もなかった。

入院時検查成績: $\mathrm{Hg} 8.9 \mathrm{~g} / \mathrm{dl}, \mathrm{Ht} 28.8 \%$ と中等度 の貧血を認めたが血液生化学, 検尿検查では異常を認 めず, 腫瘍マーカーも CEA が4.2ng/ml, CA19-9が2.0 $\mathrm{U} / \mathrm{ml}$ と正常値であった。

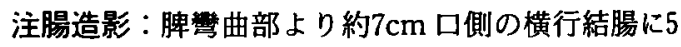
$\mathrm{cm}$ にわたる全周性不整狭窄像があり，そこから瘦孔 を介して十二指腸, 空腸へ造影剤の流出が認められた (Fig. 1).また, 瘦孔部より口側結腸の検索は造影剤の 漏出が多いため十分に行うことができなかった.

大腸内視鏡検查：肛門縁より $55 \mathrm{~cm}$ の横行結腸に全 周性の不整隆起病変を認めたが, 狭窄のためファイ バーの口側への通過は不可能で瘦孔部の確認もできな かった。また肛門縁より $30 \mathrm{~cm}$ の下行結腸に I sp 様ポ リープ, 肛門緑より $5 \mathrm{~cm} の 下$ 部直腸に I sp 型不整隆起 病変を認めた. 生検の結果, 横行結腸と直腸の病変部 は高分化腺癌と診断された。

以上より空腸に内瘦を形成した横行結腸癌, 直腸癌 と診断し，6月11日手術を施行した。

手術所見：横行結腸の腫場は, トライツ靶帯から 10 $\mathrm{cm}$ 程肛門側の空腸に直接浸潤し一塊となって手拳大 
の腫瘤を形成していた (Fig. 2). 腹水, 腹膜播種, 肝 転移は認めず。術中検索により盲腸にも隆起性腫瘍を 認めたため, 多発大腸癌を疑い結腸亚全摘術に瘦孔部 の空腸合併切除，回腸直腸吻合を行った，直腸病変に 対しては二期的に経仙骨式に全層切除した。

切除標本所見：横行結腸粘膜面に $5 \times 4 \mathrm{~cm}$ の全周性 2 型腫瘍を認めた。中心は壊死に陥って空腸に瘦孔を

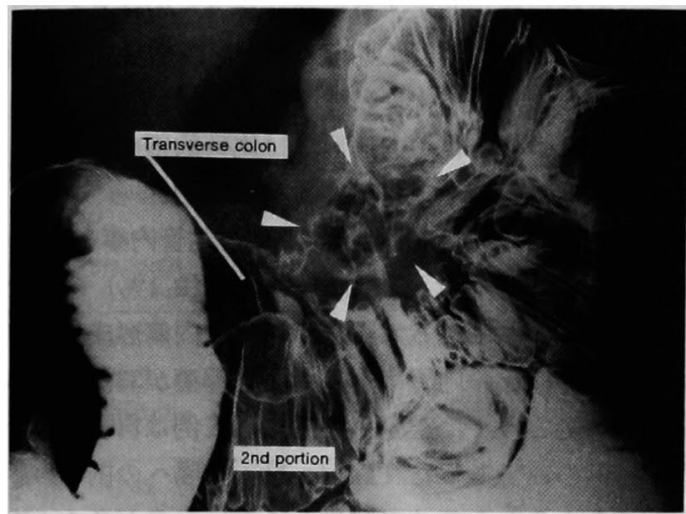

Fig. 1 Barium enema revealed the jejunum andduodenum through a fistula of the transverse colon.

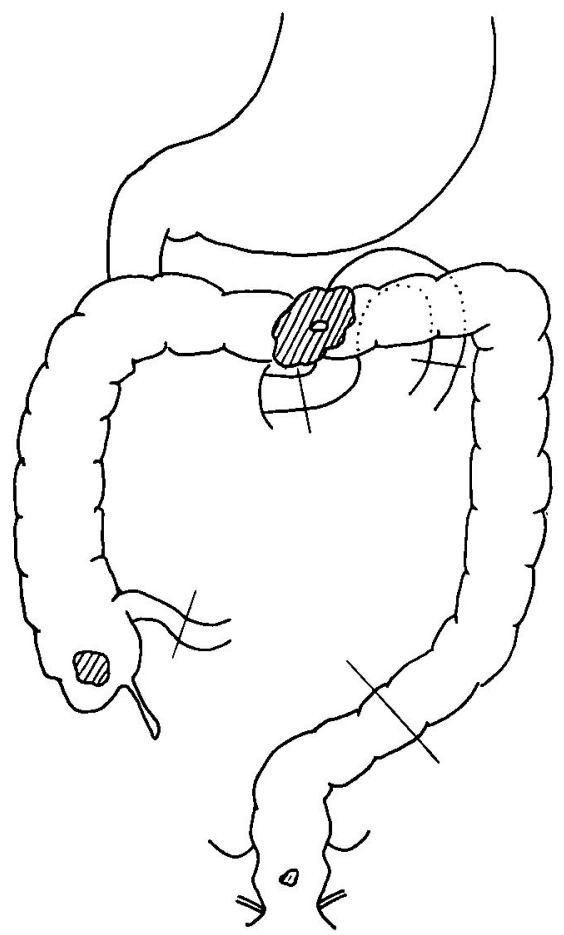

Fig. 2 The scheme of laparoscopic findings.
形成していた（Fig． 3)，盲腸にはI sp 型腫瘍を認め た、二期的切除された直腸腫場も I sp 型であった。

病理組織学的所見: 横行結腸の腫瘍は well differentiated adenocarcinoma. si (jejunum) . ly1. v0. nl. (Fig. 4). 盲腸の腫瑒は well differentiated adenocarcinoma. sm. ly0. v0. n0であった.また二期 的に切除された直腸病変は moderately differentiated
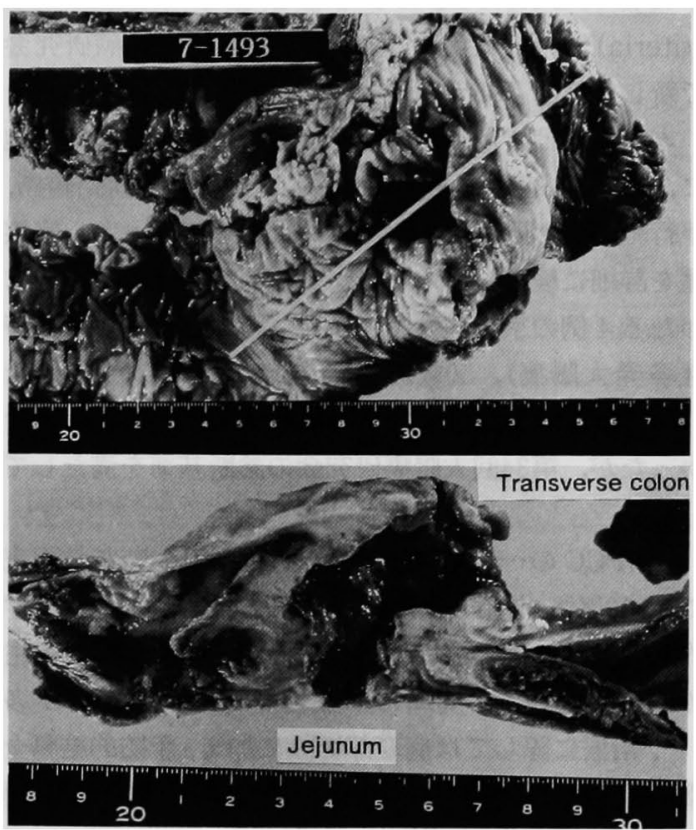

Fig. 3 Macroscopic findings of the resected specimen showed a Type 2 tumor $(5 \times 4 \mathrm{~cm}$ in size) forming a fistula to the jejunum in the transverse colon.

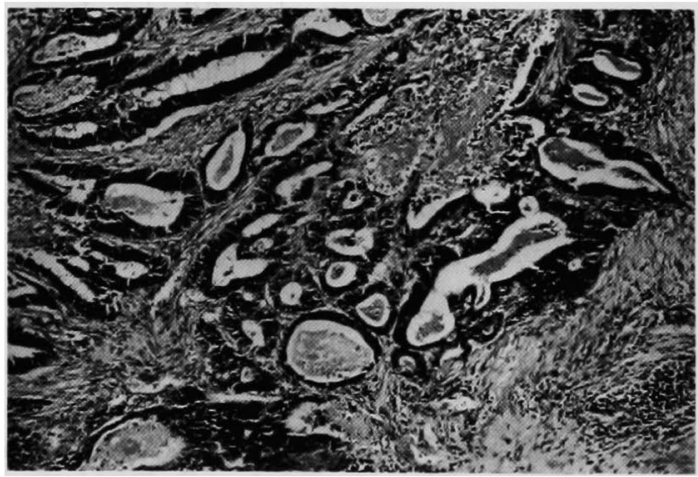

Fig. 4 Histological examination of the tumor showed well differentiated adenocarcinoma $(\mathrm{H}$. E., $\times 20$ ) 
adenocarcinoma. sm. ly0. v0. n0であった. 術後 1 年の現在, 再発の徴候もなく健在である.

\section{考察}

遺伝性非ポリポーシス大腸癌 (HNPCC) の概念は, 1913年 Warthin'1によって提唱され，その後 Lynch

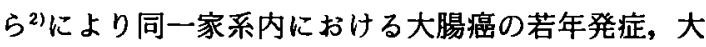
腸癌の近位側好発，子宮体癌を含む大腸癌以外の癌の 多発,常染色体優性遺伝などの特徽が報告された. 1990 年にはICG-HNPCCにより診断基準 (Amsterdam criteria $)^{3)}$ が作成され，本邦では第34回大腸癌研究会 で新しい診断基準かが提唱された.

本症例では，空腸へ内瘦を形成した横行結腸癌の他 に，直腸癌，盲腸癌を同時合併し，さらにS 状結腸癌， 下行結腸癌の既往があり 5 重複大腸癌であった。家族 歷を詳細に検索してみると，父親を発端者に 2 世代に わたる 4 例の家族内大腸癌多発（そのうち 1 例は異時 性多発大腸癌)，50歳以下の若年発症がみつかった (Fig. 5).すさての大腸癌の病理学的証明は得られな かったが，第34回大腸癌研究会の診断基準を満たして いた.

HNPCCの一般大腸癌に対する頻度は欧米の調査 で $10 \%$, 本邦ては $2.4 \%$ 程度と推定される.組織学 的には通常の大腸癌に比へ, 粘液癌, 低分化腺癌の占 める割合が高く，局所に膨張性発育を示すものが多 ( ${ }^{6)}$. 治療に際しては病変部切除に加え, 予防的結腸全 摘術が施行されることもあるが，末だ統一的見解は得
られていない, 予後は比較的良好で, 一般大腸癌と同 じかそれより良いとされる。また癌の重複数と生物学 的悪性度は必ずしも相関しないという報告もある7。 本症では，㿉孔部より口側大腸の術前検索が十分でき なかったが，術中検索で新たに盲腸癌を発見したため 多発大腸癌を考虑して結腸严全摘術を選択した，直腸 癌は比較的早期であったため，術後のQOLの観点か ら直腸は温存し二期的に経仙骨式全層切除をした。術

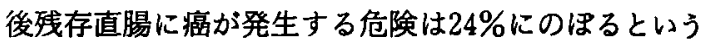
報告8)もあり，今後は定期的な大腸内視鏡による直腸 のフォローアップが重要と考えられる.

大腸癌による消化管内瘦形成は比較的稀であり，と

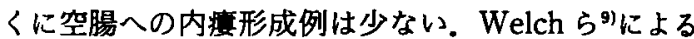
と大腸癌 2,004 例中13例 $(0.6 \%)$ に消化管内瘦を認め， そのうち空腸瘦を形成したのは 2 例（0.1\%）のみて あった．本邦における大腸癌の消化管内瘦形成報告例 は82例あり，その内訳は十二指腸結腸㿉が33例，胃結 腸瘦が20例と多く，空腸への内璂形成例は自験例を含 めて13例のみであった（Table 1)．空腸への内㿉の形 成部位をみるとトライッ鞄帯から近いものが多く, 比 較的固定された部位に浸潤し瘦孔形成することがうか がわれる。

臨床症状は古典的 trias $^{10)}$ として末消化下疡, 黄状物 の吐物，䔬臭のある㖟気があげられているが必ずしも すべての症状がそろうとは限らない，本症では突然発 症した頻回の水溶性下痢が印象的であった。
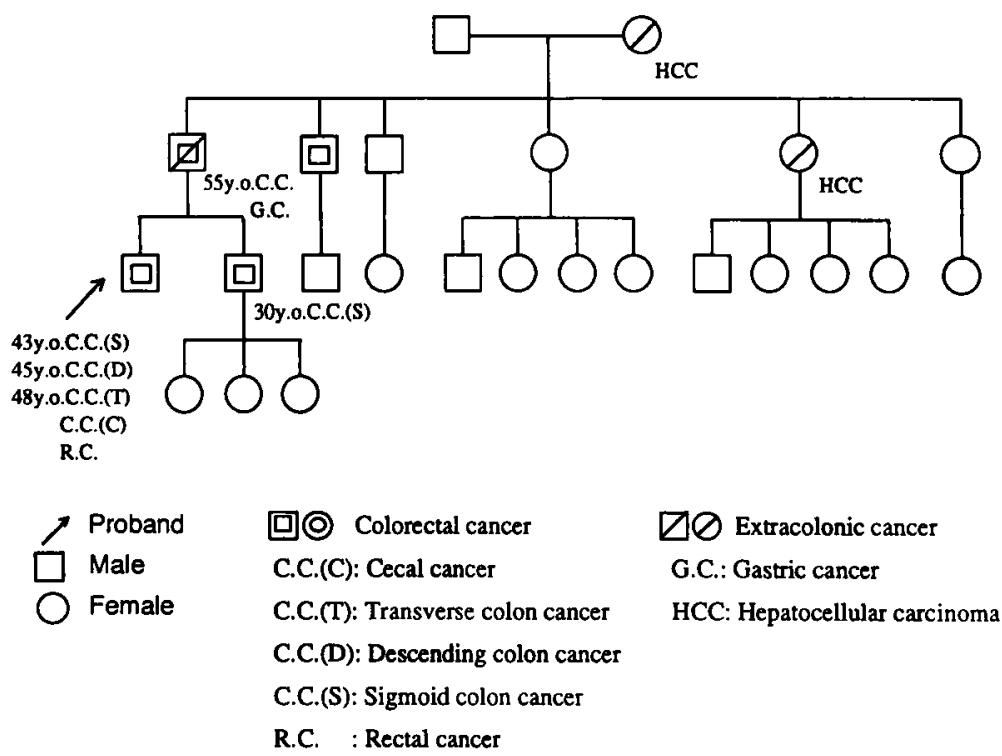

$\square \oslash$ Extracolonic cancer G.C.: Gastric cancer HCC: Hepatocellular carcinoma

Fig. 5 Pedigree of the family. 
Table 1 Reported cases of jejunocolic fistula due to colon cancer

\begin{tabular}{|c|c|c|c|c|c|c|c|c|c|c|}
\hline & Author & Year & Age.Sex & $\begin{array}{c}\text { Primary } \\
\text { lesion }\end{array}$ & $\begin{array}{l}\text { Location of the } \\
\text { internal fistula }\end{array}$ & Histology & $\begin{array}{c}\text { Lymph } \\
\text { node } \\
\text { metastasis }\end{array}$ & $\underset{\text { Liver }}{\text { metastasis }}$ & $\begin{array}{c}\text { Perito- } \\
\text { neal } \\
\text { dissemi. } \\
\text { nation }\end{array}$ & Prognosis \\
\hline 1 & Murayama & 1958 & 58. F & Descending & small bowel? & $\begin{array}{l}\text { squamous } \\
\text { cell }\end{array}$ & + & $?$ & $?$ & Alive \\
\hline 2 & Ohsawa & 1976 & 39. $\mathrm{F}$ & Transverse & Treitz $20 \mathrm{~cm}$ & adeno & - & - & - & Alive \\
\hline 3 & Satomi & 1981 & 43. $\mathrm{M}$ & Descending & Treitz $40 \mathrm{~cm}$ & $\begin{array}{l}\text { adeno } \\
\text { (well) }\end{array}$ & - & - & - & Alive \\
\hline 4 & Takeshita & 1986 & 44. M & Transverse & Treitz $0 \mathrm{~cm}$ & $\begin{array}{l}\text { adeno } \\
\text { (well) }\end{array}$ & - & - & - & Alive \\
\hline 5 & Yoshizaki & 1987 & 57. F & Transverse & Treitz $25 \mathrm{~cm}$ & $?$ & $?$ & $?$ & - & $?$ \\
\hline 6 & Okada & 1987 & 57. $\mathrm{F}$ & Transverse & Treitz $25 \mathrm{~cm}$ & adeno & $?$ & ? & $?$ & $?$ \\
\hline 7 & Fukuda & 1989 & 43. $F$ & Transverse & Treitz $50 \mathrm{~cm}$ & $\begin{array}{l}\text { adeno } \\
\text { (well) }\end{array}$ & - & - & - & Alive \\
\hline 8 & Yasunaga & 1991 & 53. $\mathrm{M}$ & Transverse & $\begin{array}{l}\text { Treitz } 5 \mathrm{~cm} \text {, } \\
\text { stomach }\end{array}$ & $\begin{array}{c}\text { adeno } \\
\text { (moderate) }\end{array}$ & - & - & - & Alive \\
\hline 9 & Saitoh & 1992 & 49. $M$ & Transverse & Treitz $10 \mathrm{~cm}$ & $\begin{array}{c}\text { adeno } \\
\text { (moderate) }\end{array}$ & - & - & - & Alive \\
\hline 10 & Hashizume & 1993 & 61. M & Transverse & $\begin{array}{l}\text { Treitz } 90 \mathrm{~cm} \text {, } \\
\text { duodenum }\end{array}$ & $\begin{array}{l}\text { adeno } \\
\text { (well) }\end{array}$ & - & - & - & Alive \\
\hline 11 & Ryuu & 1993 & 67. $F$ & Transverse & Treitz $120 \mathrm{~cm}$ & $\begin{array}{c}\text { adeno } \\
\text { (moderate) }\end{array}$ & - & - & - & Alive \\
\hline 12 & Kimura & 1997 & 78. $\mathrm{M}$ & Transverse & Treitz $150 \mathrm{~cm}$ & $\begin{array}{c}\text { adeno } \\
\text { (moderate) }\end{array}$ & - & - & - & Alive \\
\hline 13 & our case & 1997 & 48. $\mathrm{M}$ & Transverse & Treitz $10 \mathrm{~cm}$ & $\begin{array}{l}\text { adeno } \\
\text { (well) }\end{array}$ & $+(n 1)$ & - & - & Alive \\
\hline
\end{tabular}

内度の診断には，造影俞を加圧注入することのでき る注腸造影が最も適している゙11.しかし, 瘦孔部より口 側大腸の術前検索は困難なため，本症のように多発癌 合併の可能性を常に考慮に入れて術中検索を行うこと が重要である。

内瘦を形成する大腸癌の組織学的特佺として高分化 腺癌が多く, 限局性に緩徐に隣接臓器に浸潤増殖する. 周囲の炎症所見が高度のため一見して高度進行例のよ うに思われるが, リンパ節転移や腹膜播種, 肝転移を きたすことは意外に少なく比較的悪性度の低い腫瘍と 考えることができる ${ }^{21}$. 臨床所見の割には比較的予後 がよい点で HNPCC と類似した性格を持つ. 自験例で も多くは炎症性のリンパ節腫脹であり，転移を認めた のは 1 群のリンパ節に 1 個のみであった。本症では認 めなかったが, 一般の大腸癌に比べ粘液癌の頻度が比 較的高いという報告 ${ }^{13)} も$ もりこの点でも HNPCCの 組織学的特徴に共通する。

消化管内瘦合併の大腸癌はリンパ節転移や肝転移, 腹膜播種をきたすことは少ないので，原発巣と瘻孔を
形成した腸管の積極的合併切除により治㾏切除が十分 期待できる.HNPCC の本症では今後, 多臓器を含め た残存直腸の定期的なフォローアップと，近親者の発 癌早期発見のためのサーベイランスが必要と考えられ る.

\section{結語}

空腸へ内瘦を形成した遺伝性非ポリポーシス大腸癌 の 1 例を経験した.いずれも比較的若年発症であるこ と, 臨床所見の割には比較的予後がよいこと，組織学 的に粘液癌の頻度が一般大腸癌に比べ高いことなど, 共通する特徵を有しており，興味ある症例と思われた。 なお本論文の要旨は第32回中部外科学会総会にて発表し た.

\section{文献}

1) Warthin AS: Heredity with reference to carcinoma. Arch Intern Med $12: 546-555,1913$

2) Lynch HT, Krush AJ : The cancer family syndrome and cancer control. Surg Gynecol Obstet 132: 247-250, 1971 
3) Vasen HFA, Mecklin JP, Khan PM, et al: The International Collaborative Group on Hereditary non-polyposis colorectal cancer (ICG-HNPCC). Dis Colon Rectum 34 : 424-425, 1991

4）國友一史, 古味信彦, 吉川曧月 他：遺伝性大腸癌 (HNPCC). 臨床科学 28:1277-1281, 1992

5) Lynch HT: Frequency of hereditary nonpolyposis colorectal carcinoma (Lynch syndromes I and II). Gastroenterology 90 : 486489,1986

6）吉川宣輝, 柳生俊夫, 三嶋秀行：遺伝性非ポリポー シス大腸癌(HNPCC)の診断と治療. 外科 58 : $182-185,1996$

7）北川 透, 橮路政靖, 長岡椇希夫他：Cancer family syndromeにみられた四重複癌の長期生存例. 癌の臨 $42: 841$-846, 1996

8) Mecklin JP, Järvinen $\mathrm{H}$ : Treatment and follow-up strategies in hereditary non-polyposis colorectal carcinoma. Dis Colon Rectum $36: 927$ $-929,1993$

9) Welch JP, Donaldson GA: Perforative carcinoma of colon and rectum. Ann Surg 180: 734 $-740,1974$

10) Smith DL, Dockerty MB, Black BM, et al: Gastrocolic fistulas of malignant origin. Surg Gynecol Obstet 134:829-832, 1972

11) Thoeny RH, Hodgson JR, Scudamore HH : The roentgenologic diagnosis of gastrocolic and gastrojejunocolic fistulas. Am J Roentgenol $83: 876-881,1960$

12）斎藤雄史, 丹羽 傳, 丹羽篤朗他：横行結腸癌によ る空腸結腸瘦の 1 例. 日臨外医会誌 53 ：16701675,1992

13）小川道男, 王 昭亭, 水本正㴊他：横行結腸癌に伴 う胃十二指腸結腸瘦の 1 治験例. 外科治療 42 : $735-740,1980$

\title{
A CASE OF HEREDITARY NONPOLYPOSIS COLORECTAL CANCER FORMING JEJUNOCOLIC FISTULA
}

\author{
Kiyoshi ISHIGURE, Masaji YAMAUCHI, Hiroshi ASANO, Hiroyuki KOBAYASHI, \\ Takao HORIBA and Yoshio MORI* \\ Department of Surgery, Department of Pathology*, Tokai Central Hospital
}

A 48-year-old man was seen at the hospital because of sudden diarrhea and weight loss. There were previous histories of a sigmoid colon cancer and descending colon cancer. His father, uncle and brother also had a history of colonic cancers. Barium enema study and colonoscopy showed a cancer of the transverse colon with a fistula to the jejunum and a rectal cancer. Exploratory laparotomy revealed another cecal cancer. Subtotal colectomy with a partial excision of the jejunum was performed. Rectal tumor was resected later by the transsacral approach. Histologically the transverse colon cancer was well differentiated adenocarcinoma and the pathological staging was IIIa such as si, n1, p0, H0 and M(-). The cecal and rectal cancers were in early stage. A detailed family history certified the hereditary nonpolyposis colorectal cancer (HNPCC). The fistula-forming colonic cancers and HNPCC have some similar characteristics as followss: 1) The age of the onset is young. 2) They are often of low malignancy compared to the clinical findings such as local extension and number of lesions. 3) Histologically the rate of mucinous components is relatively high compared to usual colorectal cancers. 